\title{
Media, Criminal Injustice, and the Black Freedom Struggle
}

\author{
Erin Turner \\ Vanderbilt University
}

\section{Introduction}

Since the mid- $20^{\text {th }}$ century, media outlets have driven publicity for newsworthy events and shaped content for their receptive audiences. Commonly, massive movements seek publicity to attract attention and participation for protests, demonstrations, slogans, and unfortunate events. For instance, the Black freedom struggle of the 1950s through the 1970s took advantage of their traumatic narratives of oppression to attract national and international attention. Many African Americans who experienced dastardly components of a racist criminal justice system were, in turn, earning respect and power from their freedom-seeking counterparts by commodifying the emotion that fueled Black liberation efforts. ${ }^{1}$ Media, therefore, became a tool for exposing the nation to racist law enforcement and legal action. Ultimately, Black freedom struggle activists deployed media depictions of their policing, arrest, and imprisonment to be used as movement publicity, earning increased participation and advancing movement motives through this subsequent growing interest.

\section{Brief History of Victimization}

The flawed criminal justice system inspired African Americans to fight for racial equality and humanity, and the prison system offered ammunition for a battle against forms of repression. ${ }^{2}$ By sharing their stories of imprisonment, activists portrayed victimization, thereby revealing how state authorities treated them and building a campaign against unfair criminal justice. ${ }^{3}$ Unfortunately, African Americans have long been victims of criminality, beginning with

\footnotetext{
${ }^{1}$ Zoe A. Colley, Ain't Scared of Your Jail: Arrest, Imprisonment, and the Civil Rights Movement, (University Press of Florida, 2012), 4.

${ }^{2}$ Dan Berger, Captive Nation: Black Prison Organizing in the Civil Rights Era, (Chapel Hill: University of North Carolina Press, 2016), 278.

${ }^{3}$ Colley, Ain't Scared of Your Jail, 4.
} 
a democratic nation founded on settler colonialism and slavery. ${ }^{4}$ After the Civil War, the $13^{\text {th }}$ amendment emancipated enslaved African Americans, but the clause "except as a punishment for crime" created a modern form of slavery. ${ }^{5}$ Essentially, the amendment abolished slavery but created an avenue for arresting and incarcerating Black people on the basis of mild crimes such as vagrancy to further benefit economic systems. ${ }^{6}$ White society now controlled Black bodies and labor through the convict leasing system. ${ }^{7}$ Convict leasing gave white political figures and police forces an opportunity to take advantage of Black people and their descendants by subjecting "criminals" to exploitive work, harsh conditions, sexism, and further demonization by convict leasing publicity. This "modern form of slavery," along with disenfranchisement, reinforced racial segregation in the Southern United States and in the prison system overall. As decades unfolded, convict leasing became the foundation of an argument for racial injustice as a means of degradation in the criminal system.

\section{Incarceration Disparity}

Arrest and incarceration disparities extend from convict leasing to the post-WWII Black freedom struggle. State imprisonment of African Americans increased exponentially during the Civil Rights Movement. In particular, some of the inner-state admission rates, released by six Southern states with large Black populations in 1964 and 1970, represent a significant portion of state legislation violations, often relative to segregation and demonstration laws. ${ }^{8}$ In comparison, a greater proportion of incarcerated individuals in 1970 were held in city and county jails, or state prisons as opposed to federal prisons. ${ }^{9}$ As for state jail admissions, the South, a critical hub of civil rights activism, admitted $37 \%$ of the nation's jailed population in $1950,36 \%$ in 1960 , and $39 \%$ in 1970, all disproportionate when compared to other regions and populations of the country such as the Northern states. ${ }^{10}$ These incarcerations were largely attributed to civil rights activism deemed illegal, and could later be used to defend the idea that Black people were jailed statistically more than any other race.

These trends of racialized incarceration prove that African Americans have been significantly criminalized parallel to the growth of mass incarceration in America's prisons. Between 1950 and 1970, the statistics of disparate racial demonization are partially attributed to state and regional policing enforced by authorities - who in the South, tended to be connected to organizations that supported homogenized communities and overrepresentation of people of

\footnotetext{
${ }^{4}$ James Truslow Adams, The Epic of America (Little, Brown, and Company, 1932), 25-46.

${ }^{5}$ U.S. Constitution. amend. XIII, § 1 (rev. 1992).

6 13th. Directed by Ava DuVernay. Netflix Original Documentary. October 7, 2016.

${ }^{7}$ Sarah Haley, No Mercy Here: Gender, Punishment, and the Making of Jim Crow Modernity, (University of North Carolina Press, 2019); Talitha L. LeFlouria, Chained in Silence: Black Women and Convict Labor in the New South (Univ Of North Carolina Press, 2016).

${ }^{8}$ Patrick A. Langan, Race of Prisoners Admitted to State and Federal Institutions, 1926-1986. (Washington, D.C.: U.S. Dept. of Justice, Office of Justice Programs, Bureau of Justice Statistics, 1991), 6.

${ }^{9}$ Margaret Werner Cahalan and Lee Anne Parsons, Historical Corrections Statistics in the United States, 1850 $1984,79$.

${ }^{10}$ Cahalan and Parsons, Historical Corrections Statistics in the United States, 1850-1984, 76.
} 
color in prisons. For example, Bull Connor, Commissioner of Public Safety in Birmingham, Alabama during the 1960s, strongly opposed the Black freedom struggle and enforced his white supremacist ideals despite political responsibilities to protect his citizens. ${ }^{11}$ Several of these statistics are comprised of participants in the Black freedom struggle, and their criminalization, arrests, and imprisonments were heavily represented in media outlets. They used a combination of media and prison to expose their injustices and daily repression, despite some organizations who viewed purposeful submission to criminal injustice as contribution to this disparity.

\section{Policing Methodology and Peaceful Response}

Based on the theory of governmentality, state and local policing methods are implemented by federal regulations which should be interchangeable and imposed upon citizens equally. State policies, however, are shaped "around a population whose bodies, distinguished by race, poverty, and disease, serve as the basis of exclusion."12 They are also founded in national policies but are primarily determined by the perceived threat of a movement based on a culture of exclusion. For instance, the civil rights activism threatened white people in positions of power, such as the police force who reacted to activists with brutal retaliation of imprisonment and abuse.

Through a process coined "revitalization projects," the South aimed to either hold onto "old south" ideas of marginalization and criminalization of African Americans or introduce "new south" methods of policing such as surveillance and individual non-intimidating arrests in an attempt to gain both cultural and financial favors from the North. ${ }^{13}$ Representatively, the police force and Chief Laurie Pritchett of Albany noticed that many renowned civil rights activists created resistance grounded in "stereotypical southern violence" which meant that "new south" revitalization with nonviolent policing would defeat the premise of this activism. ${ }^{14}$ Locations such as Birmingham and Selma that continued to implement containment practices, which were supposed to keep the activism at bay, instead provided political ammunition to the movement in favor of racial equality. ${ }^{15}$ This "police power," intended to regulate moral life, capital, and other sociological factors alongside criminality, inspired a comparatively calm response from activists. $^{16}$

In response to police brutality, several branches of the Black freedom struggle functioned on principles of civil disobedience which, according to Martin Luther King Jr., is polite counter-

\footnotetext{
11 "Theophilus Eugene "Bull" Connor (1897-1973) (U.S. National Park Service)." National Parks Service. Accessed March 24, 2019. https://www.nps.gov/people/bull-connor.htm.

12 Randolph Hohle, "The Rise of the New South Governmentality: Competing Southern Revitalization Projects and Police Responses to the Black Civil Rights Movement 1961-1965." Journal of Historical Sociology, 22, no. 4 (2009): 497-527. doi:10.1111/j.1467-6443.2009.01367.x.

${ }^{13}$ Hohle, "The Rise of New South Governmentality," 506.

${ }^{14}$ Ibid, 506.

15 Ibid, 521.

16 "Policing the Police: A Civil Rights Story." Origins. Accessed March 24, 2019. http://origins.osu.edu/article/policing-police-civil-rights-story.
} 
friction that resists governmental slavery. ${ }^{17}$ Later, in the late-1960s and 1970s, the Black Power Movement, an extension of civil rights activism that sought a new approach to fighting racism, also included some non-violent approaches, such as the Student Nonviolent Coordinating Committee (SNCC) and the Black Panther Party. Each of these exhibitions of polite resistance were inevitably breaking laws and gaining attention for their nonnormative actions. In turn, media coverage of their leaders' arrests, policing, or imprisonment proved to be a beneficial political tactic. Exploitation of the humiliating events brought on by police response to civil activism was a common theme in Movement media releases to gain attention and sympathy from readers.

\section{Carefully Selected Activists}

In order to analyze how publicity impacted the outcome of the overall Black freedom struggle, historians must first understand several popular narratives of arrest, which were commonly publicized in the aforementioned media releases. At the beginning of his political mission, Martin Luther King Jr., a symbol of civil disobedience and member of the National Association for the Advancement of Colored People (NAACP), began the Montgomery Bus Boycott for thirteen months as a form of protest against racial segregation on buses in the Deep South. African Americans stopped riding the buses; instead, they either walked or carpooled in cabs, thereby waging an economic boycott that imperiled state and local transportation systems. In favor of the boycott, Rosa Parks sacrificed herself to the law by refusing to move out of her seat for a white person, thus submitting to arrest on December 1, 1955. She was chosen by the grassroots movement for her quiet and calm demeanor, fully aware that her actions would result in legal trouble and national publicity. ${ }^{18}$ According to her police report, she was charged by "chapter six section eleven of the Montgomery City Code" which addressed mandatory segregated seating on public transportation. ${ }^{19}$ After some time in jail, a five-minute hearing, and a charge of $\$ 10$, Parks was released. Suddenly, her arrest became a symbol of repression and her publicity ignited the movement. Her contribution was empowering through pride in her own race and loyalty to the concept of equal rights, but her inevitable punishment and criminal record were exploited for betterment of the movement.

Newspaper articles published stories of the boycott's success such as The Pittsburgh Courier's headline "Bus Boycott Effective in Dixie City" which drew Northerners' attention to a movement that kicked off with the arrest of a Black woman. ${ }^{20}$ Further, The Montgomery Advertiser published an article on December 6, 1955 titled "5,000 At Meeting Outline Boycott; Bullet Clips Bus" in which author Joe Azbell summarizes the events of Parks' arrest, 90\%

\footnotetext{
${ }^{17}$ Henry David Thoreau and Paul Lauter. Walden; And, Civil Disobedience: Complete Texts with Introduction, Historical Contexts, Critical Essays. Boston: Houghton Mifflin, 2000.

${ }^{18}$ Premilla Nadasen, Household Workers Unite (Boston Beacon Press, 2015), 8-32.

${ }^{19}$ United States, National Archives at Atlanta, Educator Resources, Browder, Et Al v. Gayle, Et Al.: Rosa Parks Arrest Record. Civil Case 1147, 1-4. https://www.archives.gov/education/lessons/rosa-parks.

20 "Bus Boycott Effective in Dixie City," The Pittsburgh Courier, December 17, 1955, Special Edition ed.
} 
participation by Black people in the boycott, and a defining moment in the movement's trajectory. He captures the referenced meeting's minutes by describing how Martin Luther King Jr. brought Rosa Parks and Fred Daniel, two recently arrested participants, in front of an audience and tagged them "tools of justice" who would serve as unifying figures of obtaining civil rights. ${ }^{21}$ All three figures represent activists' purposeful appearance in the media.

Many African Americans, such as Rosa Parks, who participated in the boycott willingly risked their run-ins with the criminal justice system. They were aware that their actions would have legal consequences and subsequent media depictions that created momentum for movement interest and participation. This knowledge suggests that they were prepared for exploitation of their crimes. Parks was the first person within the boycott to become a common headliner and her actions were followed by publication pictures of the aforementioned meeting captioned "Negroes to Continue Boycott."22 These pictures and captions describing 5,000 attendees evidenced growing interest in the cause through enumerating bodies. The St. Louis Dispatch later released a picture of four prominent boycott "religious and political leaders... after their arrest on indictments growing out of the bus boycott." 23 On January 26, 1956 Martin Luther King Jr. was arrested and imprisoned for approximately six months as law enforcement attempted to strike fear into boycotters and suppress the movement. Rather than stop the boycott, vehement reactions against King's imprisonment, in addition to a significant drop in public transportation funds, led directly to integration of buses in Montgomery, of which King was one of the first passengers.

Despite his successes and presidency of the Southern Christian Leadership Conference (SCLC), King's continuous activism came with several more arrests and instances of public and police brutality. He was sentenced to four months in jail in 1960 for participation in a sit-in, arrested in 1961 for picketing without a permit in response to a Congress on Racial Equality (CORE) interstate Freedom Ride, arrested in 1962 for leading a march in Georgia and again for a prayer vigil, jailed in 1963 for not having a permit in Birmingham, arrested in 1964 for protesting in St. Augustine, arrested in 1965 for voting rights activism in Selma, stoned in 1966 during a march in Chicago, imprisoned in 1967 for lack of permit again in Birmingham which resulted in creation of the Poor People's Campaign, and murdered in 1968 during a sanitation workers strike in Memphis - all publicized. ${ }^{24} \mathrm{He}$ clearly contributed much to the Black freedom struggle in terms of his own arrests, imprisonments, public appearances, and exploitative representation in the media. He was, additionally, a symbol of Black pride and empowerment through these various acts of bravery against a racist justice system.

Although King is often accredited with much of the struggle's accomplishments based on exercised civil disobedience, other prominent figures suffered the effects of policing in order to publicize repression and advertise civil rights campaigns. For example, in 1961 Hellen O'Neal

\footnotetext{
${ }^{21}$ Joe Azbell, "5,000 At Meeting Outline Boycott; Bullet Clips Bus." Montgomery Advertiser, December 6, 1955.

22 "Negroes to Continue Boycott," The Montgomery Advertiser, December 6, 1955.

23 "Figures in Alabama Bus Boycott," St. Louis Post-Dispatch, February 23, 1956.

24 "The King Years," The King Years - a Timeline of Martin Luther King, Jr. | King Legacy Series. Accessed March 25, 2019. http://www.thekinglegacy.org/content/king-years.
} 
McCray, Diane Nash, and Joan Trumpauer Mulholland, along with SNCC activist Stokely Carmichael, were just a few Freedom Riders supported by SNCC and CORE who rode interstate buses as a challenge to the segregation imposed upon public transportation in the South. All were jailed for their deliberate disobedience and their testimonies drew attention to both "separate but equal" inequalities and law enforcement responses. ${ }^{25}$ In 1962, Fannie Lou Hamer, leader of the Mississippi Freedom Democratic Party, and her counterparts were arrested for attempting to register to vote in Indianola; her gruesome testimony shared at the Democratic National Convention advertised the abuse she suffered in jail and made her relatable to countless other African Americans who suffered similar fates. ${ }^{26}$ These narratives of the Black freedom struggle were plastered all over national news and radio, either shaping the figures into blameless victims of racism or dangerous menaces to society_-both which garnered interest and attraction to the struggle.

\section{Power in Numbers}

In addition to individual truths of indictment, many activists were arrested or beaten en masse. Coverage of major events earned more media attention than singular situations because the drama of large numbers and angry responses drew interest. For instance, in an article published by The New York Times on July 16, 1964 entitled "Mississippi Jails 106 Court Pickets," author Claude Sitton describes the arrest of 106 court picketers at a mass voter registration event in Greenwood, Mississippi. Headlines that emphasized mass arrests contributed attention to the civil rights cause, in this case gaining voter registration access in response to a voting bill, and containment as a method of policing and controlling civil rights activism. These picketers were reportedly placed under arrest "kicking and screaming" by gunpoint and abuse, again receiving reader attention and affect. ${ }^{27}$ Other New York Times articles include "472 are arrested in Jackson March; 5 Charge Beating" 28 about pickets of a legislation meeting and "Plea to Free Rights Group Is Filed in Federal Court" covering protest of voter registration restrictions. ${ }^{29}$ Through the terrifying and encompassing language used in these national publications, and articles that spoke of massive crowds of Black and white bystanders, activists became the victims of exploitative African American criminalization while simultaneously gaining empowering publicity for the fight for Black freedom.

\footnotetext{
${ }^{25}$ Freedom Riders, directed by Stanley Nelson Jr. (Kanopy, January 2010), https://www.kanopy.com/product/freedom-riders.

${ }^{26}$ Fannie Lou Hamer, "Testimony Before the Credentials Committee," Speech, Atlantic City. http://americanradioworks.publicradio.org/features/sayitplain/flhamer.html.

${ }^{27}$ Claude Sitton, "Mississippi Jails 106 Court Pickets," The New York Times, 1964.

${ }^{28}$ Paul L Montgomery, "472 Are Arrested in Jackson March; 5 Charge Beating," The New York Times, June 15, 1965.

29 "Plea to Free Rights Group Is Filed in Federal Court,d" The New York Times, February 14, 1965.
} 


\section{Language Implications}

This publicity was supposed to create discontent with the inherent racism focalized in the South as well as support of efforts to combat disparity and inequality. Depending on geographical location and sociocultural space, media coverage catered to varying audiences. Southern newspaper article authors tended to use harsh language, emotional photographs, and hardly objective perspectives. In an op-ed article from The Montgomery Advertiser entitled "Some Observations On The Bus Boycott," the author writes "It is a proud tradition of this old city...that nowhere else in the country are the relations between different breeds and creeds so gentle, easy, and benign," but concedes that grievances of the African American community should be recognized because "evolution in oldtime custom and usage" is to be expected. By calling citizens "different breeds" the author is publishing racist language that dehumanizes people of color. ${ }^{30}$ In an article entitled "Mississippi Jails 106 Court Pickets," author Sitton explains that white people were primarily kept away from the scene except for "a fat, sloppily dressed man of middle-age" who violently reacted to an FBI agent attempting to film the arrests, likely as a method of surveillance and law enforcement review. ${ }^{31}$ Despite gruesome language describing the brutality of some arrests, Sitton managed to write through the lens of discontent with the activists' actions. His implications suggest that white supporters of the Black freedom struggle were involved in a battle where they did not belong; his beliefs were echoed by Southern Dixiecrats who rejected the participation of white people in the Black liberation efforts, such as the Freedom Rides, where white and Black people alike were beaten for their civil disobedience. ${ }^{32}$ However racist or subjective these authors exhibited themselves to be, others depicted the events with intent to gain sympathy for the atrocity of particular movement moments. As more outlets took advantage of racist moments, whether racist themselves or not, more empowerment and added attention were received by the movement for racial equality.

The Black freedom struggle was often paired with police brutality, acts of retaliation by the public, and assassination of the very figures who spoke as sufferers of racism both within society and the prison. In Alabama, after $16^{\text {th }}$ Street Baptist Church was bombed, killing four innocent African American girls in the basement, newspapers released headlines such as "Birmingham Pays Homage to Its Four Young Martyrs" with pictures of the young victims. ${ }^{33}$ The article was geared to console activists who continued to protest in the name of lives lost in the fight. Similarly, when King was suddenly assassinated in Memphis, The Chicago Tribune read "Martin Luther King Slain" which paid respects to King's faithful service to the movement and depicted his murder as motive for his followers to mourn and then move on. ${ }^{34}$ The language authors chose ultimately impacted the response of their readers. After reading summaries of mass incarcerations, cruel policing, or murder, readers were bound to feel sympathy or shock —unless

\footnotetext{
30 "Some Observations On The Bus Boycott," The Montgomery Advertiser, December 8, 1955.

${ }^{31}$ Claude Sitton, "Mississippi Jails 106 Court Pickets." The New York Times, July 17, 1964.

32 Freedom Riders, directed by Stanley Nelson Jr. (Kanopy, January 2010), https://www.kanopy.com/product/freedom-riders.

33 "Birmingham Pays Homage to Its Four Young Martyrs," The Pittsburgh Courier, September 28, 1963.

34 Joe Ruppel, "Martin Luther King Slain," Chicago Tribune (Chicago), April 5, 1968.
} 
they considered the events to be justified. With every type of reaction, the movement successfully acquired more attention and interest composed of both pity and rage.

\section{Inner-Movement Media}

Media from within the Black freedom struggle also increased participation and peaked interest by disseminating the goals and guidelines of individual activist groups. Some publications from within the movement for Black liberation were released amidst the reinterpretation of civil disobedience, termed Black Power, when activists began to use prison as the focal point of contention. ${ }^{35}$ Although the Black Power Movement occurred later than the Civil Rights Movement, it clearly represented publications released from within a segment of the Black freedom struggle that were geared to maintain informative participation. For instance, based on David Snow's theory of frame alignment and analyses of social movement participants, the Black Panther Party used a Ten-Point Program, often on fliers or in handbooks, to connect inherently racist legal action to behavioral expectations of Black Panthers. Point seven calls for an "end to police brutality and murder of Black people" and elaborates that Black persons should be armed in the event of a need for self-defense. ${ }^{36}$ Further, when leaders of the organization were arrested or imprisoned, the program publicized these incarcerations and became increasingly relevant through the real-world examples of the claims made in Party publications.

Other organizations, such as SNCC, released monthly national chapter newsletters to update readers on progress, publish editorials by activists, and provide an outlet of expression for African American authors. One archived copy includes a political cartoon featuring John D. Rockefeller and the Chase Manhattan Bank as they oppress their Black employees. It also includes a cover story about H. Rap Brown, the founder of an alliance between SNCC and the Black Panther Party surveilled and arrested for carrying a gun across state lines. ${ }^{37}$ This publication serves as an example of the bridge between different Black freedom struggle organizations who effectively used media as a tool for increasing attention and participation.

The audience of these aforementioned inner-movement publications, relative to the criminal justice system, was comprised of both Black liberation activists and their enemies. Some observers, such as the Ku Klux Klan, used these publications as an inside scoop to the activism so they could respond with protests, riots, and violence. Others, such as Freedom Riders who joined the rides from less racist locations such as Spokane, Washington or New York City, did so after a group of imprisoned Nashville students released a statement calling for assistance in filling up the Parchment Penitentiary. This was a publicity tactic to convince the Interstate Commerce Commission (ICC) to respond with fair busing legislation, which ultimately proved

\footnotetext{
${ }^{35}$ Malcolm X, “The Ballot or the Bullet.," Accessed March 27, 2019. http://www.sojust.net/speeches/malcolm_x_ballot.html.

${ }^{36}$ Heather Schoenfeld, "Organizing Against Criminal Injustice." Souls6, no. 1 (2004): 24-41. doi:10.1080/10999940490486585.

37 "Where Is H Rap Brown?" National SNCC Monthly1 (1970): 1-86.
} 
successful. ${ }^{38}$ Overall, the media releases increased participation and attention to the Black freedom struggle by strengthening members of various organizations, calling for sympathizers to join, and unintentionally informing opposing forces of unsanctioned events.

\section{Intentionality}

Another component of the Black freedom struggle was the careful selection process used to create famous activists who would be quickly and widely traced by the media. For example, Rosa Parks was chosen by the grassroots movement to become a "symbol of the mistreatment of African American women in the segregated South," and she, as expected, had her face and court case plastered all over national newspapers and newscasts. ${ }^{39}$ She was chosen on "politics of respectability" because the movement predicted that her arrest would be publicized. Her demeanor was calm and easy-going. ${ }^{40}$ According to the Women's Political Council and NAACP, "Parks' image in the Black community...made her a person upon whom they believed they could base their protest." ${ }^{41}$ Similarly, Martin Luther King Jr. had a history of preaching that made him the perfect candidate to give speeches, lead movements, and become a renowned public figure. Further, he often paralleled his extreme disobedience to Jesus, an "extremist of love."42 King's arrogance and compassion were appealing, evidenced by the Freedom Riders who rejected his refusal to join the rides but never lost respect for him. ${ }^{43}$

Movement calculations extended beyond these individual symbols. Julian Bond, a member of SNCC and insider on the Freedom Rides explains that the riders took advantage of a contradiction within the Civil Rights Movement: "On the one hand, it's nonviolent...on the other hand they're courting violence in order to attract publicity that will forward the cause." 44 The response expected from the Rides - including public rejection, rioting, and imprisonment for violations of segregation laws - was intentionally heated to draw public attention, both nationally and internationally as evidenced by American and Czechoslovakian dateline topics in a Freedom Riders documentary.

The same public response was anticipated with the March on Washington. An Alabama Journal headline read "Police in Washington Worried By Reports Of Negro March Plan" which portrayed the fear of turnout and loss of crowd control and containment expected at the march. ${ }^{45}$ Two years after the March on Washington, John Lewis and Hosea Williams attempted to lead a

\footnotetext{
${ }^{38}$ Freedom Riders, directed by Stanley Nelson Jr. (Kanopy, January 2010), https://www.kanopy.com/product/freedom-riders.

${ }^{39}$ Premilla Nadasen, Household Workers Unite (Boston Beacon Press, 2015), 21.

${ }^{40}$ Nadasen, Household Workers Unite, 22.

${ }^{41}$ Martha V. J. Bouyer, "Stony The Road We Trod...": Alabama's Role in the Modern Civil Rights Movement, (Lipscomb, Alabama: Out of the Box Consultant Services), 27.

42 "Letter from Birmingham Jail," Letter from Martin Luther King, Jr. August 1963, 4. https://web.cn.edu/kwheeler/documents/Letter_Birmingham_Jail.pdf.

43 Freedom Riders, directed by Stanley Nelson Jr. (Kanopy, January 2010). https://www.kanopy.com/product/freedom-riders.

44 Ibid.

45 "Police In Washington Worried By Reports Of Negro March Plan." Alabama Journal, June 21, 1963.
} 
group of approximately six hundred people in one of three marches, traveling from Selma to Montgomery. However, the demonstrators were brutally policed by state troopers while calmly crossing the Edmund Pettus Bridge. The results of this law enforcement-imposed abuse were captured in several photos of bleeding, tear-gassed, beaten individuals knocked down for their attempt at nonviolent protest. ${ }^{46}$ These photos, commonly captioned "Bloody Sunday" which became the unfortunate name for the marches, drew international support for the overall movement which demonstrates how activists used violence, policing, arrests, and incarceration in media to spread their truth of criminalization.

\section{Inner-Prison}

Inner-prison experiences and advertisements released by imprisoned activists were also influential on public responses and the movement's attention. For instance, Martin Luther King Jr.'s famous "Letter from Birmingham Jail" encapsulates the concepts of civil disobedience, unjust laws, Christian values, and corruption within African Americans' material reality and notions of humanity. He writes, "We know through painful experience that freedom is never voluntarily given by the oppressor; it must be demanded by the oppressed." ${ }^{77}$ With his calls for nonviolent protest based on the discrimination and injustice faced by people of color, King calls for participation in the movement similar to the vivacity already shown by white people who "have languished in filthy roach-infested hails, suffering the abuse and brutality of angry policeman" and Black people who took the brunt of segregation. ${ }^{48}$ His powerful rhetoric becomes wide-spread and highly influential on the movement, partially because it was written within the walls of oppressive confinement. He commonly used rhetoric that was impactful, long-lasting, and highly played by the media, also evidenced by the fame and quotability of his "I Have a Dream" speech. He was a powerful, influential individual working to empower movement followers.

\section{Post-Imprisonment}

As an extension of inner-prison correspondence, post-prison narratives also contributed attention to Black liberation attempts. Fannie Lou Hamer shared her grisly story in an eightminute testimony at the Democratic National Convention in Atlantic City in 1964. After her attempt at voter registration, Hamer was arrested and incarcerated where she was left alone in a cell with several men - white and Black — who beat her and left "severe bruises and massive hematoma of (her) buttocks" according to her medical record. ${ }^{49}$ She presses her audience by

\footnotetext{
${ }^{46}$ Bloody Sunday, January 30, 1972, Africana Age: The Civil Rights Movement, New York Public Library, Selma.

47 "Letter from Birmingham Jail," Letter from Martin Luther King, Jr. August 1963, 2.

https://web.cn.edu/kwheeler/documents/Letter_Birmingham_Jail.pdf.

${ }^{48}$ Ibid, 4.

${ }^{49}$ United States, Federal Bureau of Investigation. Domestic and Foreign Intelligence. Fannie Lou Hamer FBI File. Memphis 44-1063. Greenwood, MS: FBI, 1963. https://vault.fbi.gov/fannie-lou-hammer.
} 
firmly asking, "Is this America...where we have to sleep with our telephones off the hooks because our lives be threatened daily?" ${ }^{50}$ Hamer's description of the torture she endured while imprisoned for mere days after her decision to try to raise above a second-class citizen label left a mark on her listeners. Her message from within the cell signified injustice of the prison system as well as inspiration for stronger civil rights resistance.

Similarly, the diary entries released by Freedom Riders, such as Joan Trumpauer Mulholland who was jailed in the infamous Parchment Prison during the "fill the prison" escalades, were indicative of any "monotony" or brutality happening within the walls. ${ }^{51}$ Further, Diane Nash reveals in a recount of her short prison experience, which was imposed after she turned herself in, that she "desperately wanted to prepare a press release...for movement people explaining the necessity for my surrendering and serving the sentence...Staying in jail focuses attention on the injustice. ${ }^{\circ 52}$ Therefore, some of the inner-prison and post-prison testimonies shared by incarcerated activists were a ploy to suffer the injustices, speak from within confines to make a point to other activists, and advertise racism—particularly in media—as calculated demonstrations unfolded.

Whether their personal accounts were summarized by growing inspiration or disappointment with the carceral state, Black freedom struggle activists used these narratives to shape movement interest. Zoe Colley, author of Ain't Scared of Your Jail which analyzes these testimonies in relation to the overall movement, writes, "They turned the jail into a physical and symbolic battleground for the movement," which can be traced through contextual evidence of the movement and "evolution of attitudes toward arrest and imprisonment within the civil rights movement." ${ }^{13}$ For example, planned protests such as the Freedom Rides in the early 1960s represented a shift from sit-in demonstrations to "jail-in" protests where prisoners refused bail and chose incarceration. ${ }^{54}$ They were deliberately allowing exploitation of their suffering to benefit the movement through attention to unheard of acts.

However, some civil rights organizations viewed filling the jails to be an erasure of the sacrifices, money, and work that had already been done. The NAACP, for instance, fought to break the disparity of policing and imprisonment for African Americans and feared that willingness to submit to jailing would be nothing more than "a social stigma." ${ }^{55}$ According to several activists, such as protestors in the Freedom Summer of 1964, becoming a part of the prison system allowed them to review the definition of criminality. This definition was inherently skewed by the criminal justice system but determined by other incarcerated

\footnotetext{
${ }^{50}$ Fannie Lou Hamer, "Testimony Before the Credentials Committee." Speech, Atlantic City. http://americanradioworks.publicradio.org/features/sayitplain/flhamer.html.

${ }^{51}$ Joan Trumpauer Mulholland, "Arrest and Trial; Jail," Hands on the Freedom Plow: Personal Accounts by Women in SNCC (Urbana: University of Illinois Press, 2012), 68.

${ }^{52}$ Diane Nash, Hands on the Freedom Plow: Personal Accounts by Women in SNCC (Urbana: University of Illinois Press, 2012), 82.

${ }^{53}$ Zoe A. Colley, Ain't Scared of Your Jail: Arrest, Imprisonment, and the Civil Rights Movement (University Press of Florida, 2012), 4.

${ }^{54}$ Ibid, 43.

${ }^{55}$ Colley, Ain't Scared of Your Jail, 39.
} 
individuals and defined by the charges pressed against the activists. ${ }^{56}$ Prison protests remained fairly subtle and directed toward law enforcement practices such as undeserved beatings or arrests until some members of the Black freedom struggle gained a stronger interest in prison reform, police brutality, and justice. At this point in the 1960s, activism morphed into "Black power" rhetoric that included "armed self-defense, political empowerment, economic independence, Black separatism, racial pride and antiwhite sentiment."

The Black Power movement, created by the 27-times-arrested SNCC leader Stokely Carmichael in the late 1960s, used the carceral state as a tool for publicity and momentum for the Civil Rights Movement. Black Power activists "made opposition to state repression in the form of policing and imprisonment a fundamental ingredient of political struggle" through their selfdefense campaigns and willingness to be incarcerated. ${ }^{58}$ They noticed that prisons and jails were a form of suppressing seemingly radical ideas of equal rights and desegregation within the southern Civil Rights Movement and expanded it to include more urban areas with a new, militarized response. So, although prideful incarceration is significantly and concretely evidenced by the Black Power movement, Black freedom activists under the terms of civil disobedience and nonviolence began the trend. Dan Berger, author of Captive Nation, echoes this sentiment as he writes, "Their entanglements with the most dreaded southern institutions facilitated their ideas that race and freedom were grounded in a carceral experience." 59

Confirming the connection between civil rights and Black liberation, in Prison Power, Lisa Corrigan analyzes the use of prison rhetoric and organizing to explain the transcendence of the movements by suggesting, "prison became the critical space for the transformation from civil rights to Black Power." ${ }^{\prime 60}$ Further, activists were forced to consider flaws of the implementation of civil disobedience, instead searching for new approaches to shaping depictions of imprisoned activists and the movement's overall intentions. So, "violence became a large part of the conversation as (mostly) white media outlets pushed back against a more radical civil rights agenda." ${ }^{161}$ Regardless of the vivacity with which media responded to the movement's rhetoric, both civil rights and Black Power activists took advantage of discrimination within policing and imprisonment to expose their repression and build interest. Their stories became the basis for headlines regarding the Black freedom struggle as they battled oppression with prison as the weapon of choice.

\footnotetext{
${ }^{56}$ Colley, Ain't Scared of Your Jail, 101.

${ }^{57}$ Ibid, 103.

${ }^{58}$ Dan Berger, Captive Nation: Black Prison Organizing in the Civil Rights Era, (Chapel Hill: University of North Carolina Press, 2016), 82.

59 Berger, Captive Nation, 25.

${ }^{60}$ Corrigan, Lisa M. Prison Power: How Prison Influenced the Movement for Black Liberation, (Jackson: University Press of Mississippi, 2017), 4.

61 Ibid, 27.
} 


\section{Legislative Responses}

Amidst all of this media-shaped civil rights action, the U.S. government took steps toward racial equality in response to the movement. In 1964, they passed the Civil Rights Act to end segregation of public places and discrimination of hiring practices for the labor sector. One year later, the Voting Rights Act was passed to allow African Americans a chance at voter registration and elections. Despite the policy changes in the 1960 s, society had trouble digesting the new laws and acting accordingly. Consequently, prisons and jails were still disproportionately filled with more African Americans than white people, and some of those individuals were activists. After achieving civil rights laws, some civil rights activists considered the journey to be over. However, others understood that the war was not won, and the fight turned into a search for liberation in addition to pride and humanity - the agenda of the Black Power Movement. Through the next few decades, legislation was implemented with more accuracy, and milestones were met on account of civil rights activism, but incarceration and criminalization did not disappear in the slightest. In contemporary society, mass incarceration is greatly representative of a racialized criminal justice system that deems one race superior to others. ${ }^{62}$ Despite shortfalls of the movement as a whole, the Black freedom struggle and Black liberation were directly shaped by exploitative and empowering media mixed with policing, arrests, and imprisonment.

\section{Conclusion}

In the fight for freedom and equality, African Americans were often criminalized and demonized through arrests as a method of creating a divide between first and second-class citizens. Racism triumphed through the disparity and rise of incarceration, but the Black freedom struggle gained traction through media releases and coverage of activist victimization within calculated resistance. Media often focused on massive demonstrations, blatant disobedience of racist legislation that led to arrests or police brutality, central figures of the movement who were deemed popular and respectable, and heart-breaking testimonies of individuals directly impacted by the enemy of the movement: racism. As activists discovered the impact of using prison and policing to gain more attention, the movement developed, and their intentions transformed from complacency with civil disobedience to self-defense and nationalist-based rhetoric. As the movement progressed and discovered new media approaches that caught attention for activists, the public responded appropriately and contributed to the movement with interest and participation. Continued research could potentially reveal modern forms of media used to attract movement interested to battle incarceration and forms of oppression.

${ }^{62}$ Wendy Sawyer and Peter Wagner, "Mass Incarceration: The Whole Pie 2019," Mass Incarceration: The Whole Pie 2019 | Prison Policy Initiative. Accessed April 14, 2019. https://www.prisonpolicy.org/reports/pie2019.html. 


\section{References}

\section{Primary Sources}

Archives, Freedom. Freedom Archives Search Engine. Accessed March 25, 2019.

https://search.freedomarchives.org/search.php?view_collection=1016\&title=SNCC

Newsletter.

Azbell, Joe. "5,000 At Meeting Outline Boycott; Bullet Clips Bus." Montgomery Advertiser, December 6, 1955.

"Birmingham Pays Homage to Its Four Young Martyrs." The Pittsburgh Courier, September 28, 1963.

Black Panther Party Platform, Program, and Rules. Accessed March 25, 2019. https://www.historyisaweapon.com/defcon1/bpp.html.

Blake, J. Herman. "The Caged Panther: The Prison Years of Huey P. Newton." Journal of African American Studies 16, no. 2 (2011): 236-48. doi:10.1007/s12111-011-9190-1.

Bloody Sunday. January 30, 1972. Africana Age: The Civil Rights Movement, New York Public Library, Selma.

Bouyer, Martha V. J. "Stony The Road We Trod...": Alabama's Role in the Modern Civil Rights Movement. Lipscomb, Alabama: Out of the Box Consultant Services.

"Bus Boycott Effective in Dixie City." The Pittsburgh Courier, December 17, 1955, Special Edition ed.

Cahalan, Margaret Werner, and Lee Anne Parsons. Historical Corrections Statistics in the United States, 1850-1984. 79.

"Civil Rights Topic." Topics. Accessed March 25, 2019. https://www.newspapers.com/topics/civil-rights/.

"FBI Files: Civil Rights." The Black Vault. June 20, 2018. Accessed March 25, 2019. https://www.theBlackvault.com/documentarchive/fbi-files-civil-rights/\#.

"Figures in Alabama Bus Boycott." St. Louis Post-Dispatch, February 23, 1956.

Freedom Riders. Directed by Stanley Nelson, Jr. Kanopy. January 2010. https://www.kanopy.com/product/freedom-riders.

Hamer, Fannie Lou. "Testimony Before the Credentials Committee." Speech, Atlantic City. http://americanradioworks.publicradio.org/features/sayitplain/flhamer.html. 
Holsaert, Faith S. Hands on the Freedom Plow: Personal Accounts by Women in SNCC. Urbana: University of Illinois Press, 2012.

"Letter from Birmingham Jail." Letter from Martin Luther King, Jr. August 1963. 1-6. https://web.cn.edu/kwheeler/documents/Letter_Birmingham_Jail.pdf.

Langan, Patrick A. Race of Prisoners Admitted to State and Federal Institutions, 1926-1986. Washington, D.C.: U.S. Dept. of Justice, Office of Justice Programs, Bureau of Justice Statistics, 1991.

"Lone Negro Waits at Bus Stop." The Montgomery Advertiser, December 5, 1955.

Montgomery, Paul L. "472 Are Arrested in Jackson March; 5 Charge Beating." The New York Times, June 15, 1965.

"'Negro's Arrest, \$14 Fine May Lead To Court Test on Bus Segregation." The Morning Call (Allentown, PA), December 6, 1955.

"Negroes to Continue Boycott." The Montgomery Advertiser, December 6, 1955.

"Plea to Free Rights Group Is Filed in Federal Court." The New York Times, February 14, 1965.

"Police In Washington Worried By Reports Of Negro March Plan." Alabama Journal, June 21, 1963.

"Policing the Police: A Civil Rights Story." Origins. Accessed March 24, 2019. http://origins.osu.edu/article/policing-police-civil-rights-story.

Ruppel, Joe. "Martin Luther King Slain." Chicago Tribune (Chicago), April 5, 1968.

Schoenfeld, Heather. "Organizing Against Criminal Injustice." Souls6, no. 1 (2004): 24-41. doi:10.1080/10999940490486585.

Sitton, Claude. "Mississippi Jails 106 Court Pickets." The New York Times, July 17, 1964.

"Some Observations On The Bus Boycott." The Montgomery Advertiser, December 8, 1955.

U.S. Constitution. amend. XIII, § 1 (rev. 1992).

United States. Federal Bureau of Investigation. Domestic and Foreign Intelligence. Fannie Lou Hamer FBI File. Memphis 44-1063. Greenwood, MS: FBI, 1963. https://vault.fbi.gov/fannielou-hammer.

United States. National Archives at Atlanta. Educator Resources. Browder, Et Al v. Gayle, Et Al.: Rosa Parks Arrest Record. Civil Case 1147. 1-4. https://www.archives.gov/education/lessons/rosa-parks. 
"Where Is H Rap Brown?" National SNCC Monthly 1 (1970): 1-86.

\section{Secondary Sources}

13th. Directed by Ava DuVernay. Netflix Original Documentary. October 7, 2016.

"Angela Davis." Biography.com. January 16, 2019. Accessed March 25, 2019. https://www.biography.com/people/angela-davis-9267589.

"Angela Davis (January 26, 1944)." National Archives and Records Administration. Accessed March 25, 2019. https://www.archives.gov/research/african-americans/individuals/angeladavis.

Berger, Dan. Captive Nation: Black Prison Organizing in the Civil Rights Era. Chapel Hill: University of North Carolina Press, 2016.

"Black Power." National Archives and Records Administration. Accessed March 25, 2019. https://www.archives.gov/research/african-americans/Black-power.

The Civil Rights Movement: 1919-1960s, Freedom's Story, TeacherServe ${ }^{\circledR}$, National Humanities Center. Accessed March 25, 2019. http://nationalhumanitiescenter.org/tserve/freedom/1917beyond/essays/crm.htm.

Colley, Zoe A. Ain't Scared of Your Jail: Arrest, Imprisonment, and the Civil Rights Movement. University Press of Florida, 2012.

CORE. Accessed March 25, 2019. https://350cr.blogs.brynmawr.edu/pastcampaigns/montgomery-bus-boycott/.

Corrigan, Lisa M. Prison Power: How Prison Influenced the Movement for Black Liberation. Jackson: University Press of Mississippi, 2017.

Gore, Dayo F. Radicalism at the Crossroads: African American Women Activists in the Cold War. New York: New York University Press, 2011.

Haley, Sarah. NO MERCY HERE: Gender, Punishment, and the Making of Jim Crow Modernity. Place of Publication Not Identified: University of North Carolina Press, 2019.

Hohle, Randolph. "The Rise of the New South Governmentality: Competing Southern Revitalization Projects and Police Responses to the Black Civil Rights Movement 19611965." Journal of Historical Sociology22, no. 4 (2009): 497-527. doi:10.1111/j.14676443.2009.01367.x.

James Truslow Adams, The Epic of America (Little, Brown, and Company, 1932), 25-46. 
"The King Years." The King Years - a Timeline of Martin Luther King, Jr. | King Legacy Series. Accessed March 25, 2019. http://www.thekinglegacy.org/content/king-years.

Laurie B. Green, Battling the Plantation Mentality, (The University of North Carolina Press, 2007), 254.

LeFlouria, Talitha L. Chained in Silence: Black Women and Convict Labor in the New South. S.1.: Univ Of North Carolina Pr, 2016.

"The Nobel Peace Prize 1964." NobelPrize.org. Accessed March 25, 2019. https://www.nobelprize.org/prizes/peace/1964/king/biographical/.

Premilla Nadasen, Household Workers Unite (Boston Beacon Press, 2015).

Sawyer, Wendy, and Peter Wagner. "Mass Incarceration: The Whole Pie 2019." Mass Incarceration: The Whole Pie 2019| Prison Policy Initiative. Accessed April 14, 2019. https://www.prisonpolicy.org/reports/pie2019.html.

"Theophilus Eugene "Bull" Connor (1897-1973) (U.S. National Park Service)." National Parks Service. Accessed March 24, 2019. https://www.nps.gov/people/bull-connor.htm.

Thoreau, Henry David and Paul Lauter. Walden; And, Civil Disobedience: Complete Texts with Introduction, Historical Contexts, Critical Essays. Boston: Houghton Mifflin, 2000. 